\title{
Dynamics of Macroeconomic Adjustment in a Globalized Developing Economy: Growth, Accumulation and Distribution, Turkey 1969-1999
}

\author{
Kivilcim Metin-Ozcan , Ebru Voyvoda \& A. Erinç Yeldan
}

To cite this article: Kivilcim Metin-Ozcan , Ebru Voyvoda \& A. Erinç Yeldan (2001)

Dynamics of Macroeconomic Adjustment in a Globalized Developing Economy: Growth, Accumulation and Distribution, Turkey 1969-1999, Canadian Journal of Development Studies/

Revue canadienne d\&apos;\&eacute;tudes du d\&eacute;veloppement, 22:1, 219-253, DOI:

$10.1080 / 02255189.2001 .9668808$

To link to this article: https://doi.org/10.1080/02255189.2001.9668808

\section{曲 Published online: 15 Feb 2011.}

Submit your article to this journal 준

Џlll Article views: 149

Citing articles: 9 View citing articles 4 


\title{
Dynamics of $\mathcal{M}$ acroeconomic $\mathcal{A}$ djustment in a Globalized Developing Economy: Growth, Accumulation and Distribution, Turkey 1969-1999*
}

\author{
Kivilcim Metin-Ozcan \\ Ebru Voyvoda \\ A. Erinç Yeldan
}

\begin{abstract}
Our purpose in this paper is to establish stylized facts of the Turkish macroeconomic adjustments using data from 1969 to 1999 . We adopt a traditional a priori definition of business cycles as cyclical co-movements of economic variables such as public, private and construction investments, trade balance, labour productivity, wages and fiscal accounts with the cyclical component of real GDP. We also incorporate in our analysis an investigation of the cyclical components of exchange rates, interest rates, price inflation, and the monetary aggregates. Our quantitative findings reveal a robust and significant positive relationship between public and private investments and real GDP growth, suggesting the presence of "crowding in" effects of public investment. Trend growth of manufacturing wages and average labour productivity are loosely associated over the whole period, and the rapid gains in productivity in the post-1980 reform era are not observed to be materialized as gains in remunerations of wage labour. We also find a significant negative correlation of manufacturing wages with merchandise exports and the exchange rate; and document further evidence of the strong negative correlation between variations in consumer prices and production.
\end{abstract}

* Previous versions of this paper were presented at the Gazi University conference on "The Anatomy of the Crisis," May 1999; the 3rd International Conference on Economics by the METU, Ankara, September, 1999; and the 18th Annual Conference of the Middle East Economic Association, held with the ASSA meetings, Boston, January 2000. The author names are in alphabetical order and do not necessarily imply authorship seniority. We are grateful to Merih Celasun, Irma Adelman, Oktar Türel, Emre Alper, Fatih Özatay, Refet Gürkaynak, Erdem Basçı, Mehmet Caner, Xinshen Diao, and Terry Roe for their encouragement and valuable comments at various stages of this research. 


\section{RÉSUMÉ}

Cet article vise à établir des faits sur les ajustements macroéconomiques qui ont été réalisés en Turquie de 1969 à 1999. Pour ce faire, les auteurs adoptent une définition a priori traditionnelle du cycle économique, à savoir les mouvements cycliques des variables économiques telles que les investissements publics, privés et dans le secteur du bâtiment, la balance commerciale, la productivité de la main d'ouvre, les salaires et les comptes fiscaux, conjointement avec les mouvements cycliques $d u$ PIB. Ils analysent en outre les comportements cycliques du taux de change, des taux d'intérêt, de l'inflation des prix et des agrégats monétaires. Leurs résultats quantitatifs révèlent l'existence d'une relation significative et positive entre les investissements publics et privés et la croissance du PIB, ce qui confirme l'existence d'un effet "crowding in " sur l'investissement public. Durant la période étudiée, les auteurs ont observé un lien d'une part entre la croissance des salaires industriels et celle de la productivité moyenne de la main d'ouvre, et d'autre part entre le fait que les gains rapides acquis par la productivité après la réforme de 1980 ne sont pas enregistrés comme des gains dans le revenu salarial de la main-d'ouvre. Ils ont aussi identifié une corrélation significative et négative entre les salaires industriels et les exportations des marchandises et les taux de change. En outre, ils ont noté l'existence d'une corrélation négative entre les variations des prix à la consommation et la productivité.

\section{INTRODUCTION}

The concept of business cycles has a long tradition of research in economics dating back to Ricardo and Marx. As an indicator of the dynamics of growth and accumulation, the concept is directly embedded in the quest of "the laws of motion of capital" in the realm of classical economics. Recently, there has been renewed interest in the empirics of business cycles and economic growth. A variety of empirical evidence had revealed that fluctuations in national output are correlated with many macroeconomic and political variables, including many that are under the direct control of the government policies. ${ }^{1}$ Together, these efforts strive to explain many of what Burns and Mitchell (1946) identified as the facts of business cycles, which Lucas (1977) later redefined as "repeated deviations of output from some trend."

The purpose of this paper is to identify and study the main stylized facts characterizing the dynamic macroeconomic adjustments of the globalizing

1. Part of this literature is surveyed in Barro and Sala-i-Martin (1995), Levine and Renelt (1992), and Barro (1991). On the business cycles literature, see Lucas (1977); King, Plosser and Rebelo (1998a, 1988b) and the recent symposium papers by Romer, Basu and Taylor and Zarnowitz in J. of Economic Perspectives (1999). 
developing economy of Turkey from 1969 to the present. Although a number of recent studies examine business cycles experienced in industrialized economies, ${ }^{2}$ there is a lack of similar studies in developing economies, with a notable break provided recently by Agenor, McDermott and Prasad (1999) and Hoffmester and Roldos (1997). ${ }^{3}$ Consequently, we also attempt to compare our findings for a developing economy with those obtained for the developed industrial economies and contribute to the empirics of development macroeconomics (as emphasized in Agenor and Montiel [1996], for example). We further advance the hypothesis that the research paradigm outlined with this tradition would provide the necessary empirical pillars for constructing analytical models of macroeconomic adjustment and economic fluctuations which incorporate the distinguishing features relevant for the developing economies. These, in turn, could have important policy implications which would be crucial in the design and implementation of the structural adjustment stabilization programs.

After a long period of following an inward-looking, import-substitutionist pattern of growth, Turkey initiated an extensive reform process in 1980 aimed at integrating with the world commodity and financial markets. During this process, first the existing system of multiple exchange rates was abandoned and quantitative restrictions on imports were eliminated. Capital account liberalization was then completed with the introduction of full convertibility of the Turkish lira and the elimination of all controls on foreign capital flows in 1989. Currently, the Turkish economy operates under the conditions of a truly open economy - a macroeconomic environment where its capital account is entirely liberalized and the process of financial deregulation is complete. In this environment, many of the instruments of monetary and fiscal control have been transformed and the constraints of macro-equilibrium have undergone major structural change.

In what follows, we adopt a traditional a priori definition of business cycles as cyclical co-movements of economic variables such as public and private investments, trade balance, wage rates of different labour categories, and fiscal accounts with the cyclical component of real gross domestic product (GDP).

2. See, for example, Hodrick and Prescott (1997); Pedersen (1998); Chadha and Prasad (1994); Backus and Kehoe (1992); Blackburn and Ravn (1992); Englund, Torsten and Svensson (1992); Brandner and Neusser (1992); Kydland and Prescott (1990); Romer (1994) and Lucas $(1977,1980)$. See also, Van Els (1995) for a survey of the related literature.

3. Alper (1998) also provides a recent study of the business cycle facts of the Turkish economy. However, Alper's approach is limited in its time frame and coverage, addressing only the monetary aggregates, prices and nominal output. 


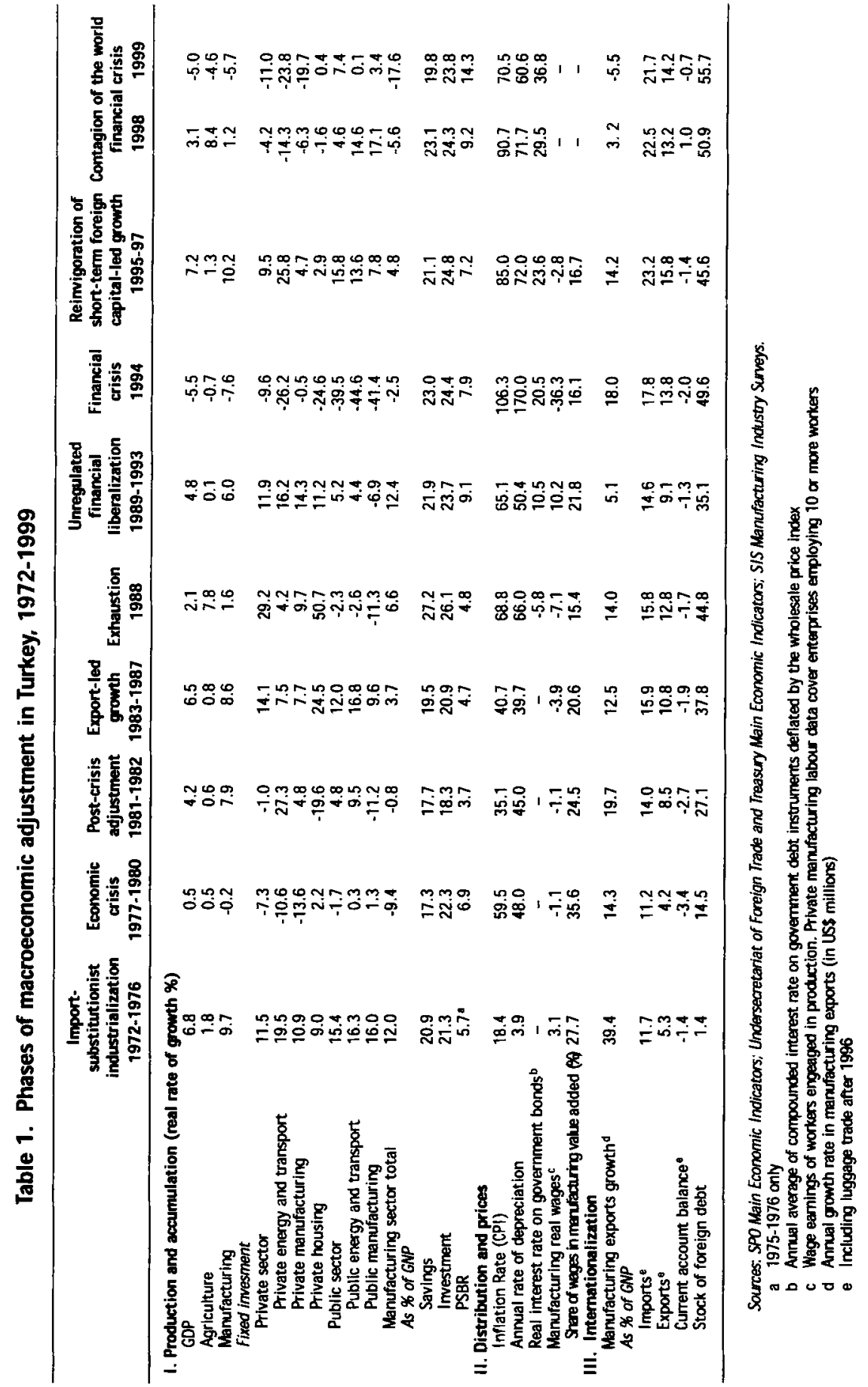


Our analysis also includes an investigation of the cyclical behaviour of exchange rate and price inflation as measured in alternative forms.

Our enquiry uses annual data for 1969 to 1999 and decompose the relevant time series into a trend component and cyclical deviations around the trend. While there are many techniques for dealing with this problem, ${ }^{4}$ we adopted the Hodrick-Prescott (1997) methodology because it seems to present one of the most widely used decomposition filters in modern theory of the business cycles, thus enabling us to draw direct inferences from previous results obtained for the developed industrialized economies.

The paper is organized into three sections. Section I provides an overview of the recent development path of the Turkish economy, with three major subperiods: the import-substitutionist industrialization period 1969-1979; the commodity trade liberalization and export promotion period 1980-1988; and the post-financial liberalization period from 1989 to the present. Section II introduces and executes our analytical methodology, and section III investigates our quantitative results. The conclusion summarizes our findings.

\section{PHASES OF MACROECONOMIC ADJUSTMENT IN TURKEY, 1969-1999}

The recent evolution of the Turkish economy has experienced three distinct cycles of growth, crisis and adjustment in the last three decades (table 1). The first covers broadly the period until 1979 , with its main attribute being the deepening of the import-substitutionist industrialization strategy. This period, often called the second phase of import substitution, was characterized by the implementation of a vigorous public investment programme which aimed at expanding domestic production capacity in heavy manufacturing and capital goods such as machinery, petrochemicals and basic intermediates. Foreign trade was under heavy protection through quantitative restrictions and a fixed exchange rate regime which, on average, was overvalued in terms of purchasing parity. The state was both an investing and a producing agent, with state economic enterprises serving as the major tools for fostering industrialization targets.

In retrospect, the underlying political economy basis of the import-substitutionist industrialization strategy was a grand yet delicate alliance among the bureaucratic elites, industrial capitalists, industrial workers and the peasantry

4. For an evaluation of the robustness of alternative techniques of decomposition of the business cycles, see Cogley (1997), Cogley and Nason (1995) and King and Rebelo (1993). 
(Boratav 1983; Boratav, Keyder and Pamuk 1984). Accordingly, private industrial profits were fed from two sources: First, the protectionist trade regime, often implemented through strong non-tariff barriers, enabled industrialists to capture oligopolistic profits and the rents originating from a readily available, protected domestic market. Second, the existence of a public-enterprise system with a strategic role of producing cheap intermediates through artificially low, administered prices enabled the private industrial enterprises (and the rural economy) to minimize material input costs. Industrialists, in turn, "accepted" the conditions of a general rise in manufacturing wages and an agricultural support programme that caused the domestic terms of trade to favour agriculture.

The import-substitutionist development strategy reached its limits beginning 1976, when the financing of the balance of payments and industrial investments became difficult. The foreign exchange crisis of 1977-1980 brought together the cessation of civilian democracy and the imposition of a new constitution and labour codes regulating industrial relations under a military regime.

Growth was re-invigorated following the introduction of a structural adjustment programme in January 1980 under the auspices of international agencies such as the World Bank and the IMF. The period 1981-1987 was marked by commodity trade liberalization and export promotion, along with price reform aimed at reducing the state's role in economic affairs. The existing system of a fixed exchange rate administration was replaced by a flexible crawling-peg regime, and a complex system of direct export subsidization was introduced. These new systems were the main instruments for the promotion of exports and the pursuit of macroeconomic stability. ${ }^{5}$

During the 1981-1987 period, export revenues increased at an annual rate of $10 \%$. GDP rose at an annual rate of $4.2 \%$ in $1981-1982$, and $6.5 \%$ between 1983 and 1987. The period was also characterized by a severe erosion of wage incomes through hostile measures against organized labour. The suppression of wages was instrumental in both lowering production costs and squeezing domestic absorption capacity. This generated an exportable surplus, which found its way to the newly growing Middle Eastern markets with the heavy use of export subsidies. Consequently, the share of wages in private manufacturing

5. See Boratav and Türel (1993), Senses (1994), Celasun and Rodrik (1989), Uygur (1993), and Celasun (1994) for a thorough overview of the post-1980 Turkish structural adjustment reforms. For a quantitative assessment of the export subsidization programme, see Milanovic (1986) and Togan (1993). 
value-added receded from $30 \%$ to $20 \%$ and in public manufacturing, from $27 \%$ to $15 \%$ between 1980 and 1988 . In this process, the average rate of profit margins in private manufacturing increased from $31 \%$ to $38 \%$.

In the 1980s, public sector balances were generally maintained, and the public sector borrowing requirement (PSBR) was about $4.7 \%$ of GDP. Domestic saving rates reached $20 \%$, and the share of investments increased to $21 \%$ of aggregate GDP. However, the composition of total fixed investments displayed adverse trends at the sectoral level from the point of view of strategic targets. In fact, as private sector gross fixed investments increased by $14.1 \%$ during 1983-1987, only a small portion of this amount was directed at manufacturing. The rate of growth of private manufacturing investments was around half of that figure, at only $7.7 \%$ per year, and did not reach its pre-1980 levels in real terms until the end of 1989 . This resulted in a significant anomaly in the official stance toward industrialization: in a period where outward orientation was supposedly directed at increased manufacturing exports through significant price and subsidy incentives, the distribution of investments revealed a declining trend for the sector. As shown in table 1 , much of the expansion in private manufacturing investments originated in the pull from housing investments, which expanded by an annual average of $24.5 \%$ during $1983-1987$ and by $50.7 \%$ in 1988 . Thus, the main dilemma of the sectoral patterns of investment in Turkey seems to be over its allocation between housing and the traded/productive sectors of the economy, rather than the classic argument between a crowding-out pattern of public and private investments (see also Uygur 1999; Senses 1994; Celasun 1994). The implications of this non-conformity between the stated foreign trade objectives toward manufacturing exports and the realized patterns of accumulation away from manufacturing were some of the main structural deficiencies of the export-oriented growth strategy of the 1980s and, in our view, played a crucial role in the failure to maintain the export promotion programme as a sustainable development strategy.

This unbalanced structure failed to generate the necessary accumulation patterns for achieving sustained growth and ran out of steam by the end of the decade. The artificial growth path generated through wage suppression and price subsidies reached its economic and political limits by 1988 . All economic indicators for 1988 signal a stagflationary macro environment. Furthermore, the real exchange rate started to appreciate for the first time since the inception of export orientation. Thus, the classical accumulation episode based on wage suppression had come to an end by 1989 (see also Yeldan 1995 and 1999). At the same time, real wage earnings entered a period of recovery following 
the gains of union movement and also the new wave of populist pressures. Real wages in manufacturing increased at an annual rate of $10.2 \%$ from 1989 to 1993 (table 1).

In what followed, it was clear that the opening up of the Turkish economy through commodity trade liberalization had reached its limits and that the next steps would require new polices toward the liberalization of financial markets and full foreign exchange transactions. The most important of the many economic and institutional reforms undertaken after 1988 was the full liberalization of the capital account and the declaration of the domestic currency, the lira, as convertible in the world exchange markets. Through these reforms, the Turkish economy completed the second phase of full integration into world markets by the end of the 1980s.

In retrospect, it could be argued that the post-1988 populism could have been financed by expanding the tax base over the so-called unrecorded private commercial transactions, and by moving toward a fair tax system. The government's strategic preference, however, was the maintenance of its stance toward erosion of taxable capital incomes and absorption of all costs of adjustment in favour of profit incomes against the culminating wage pressures (Boratav, Yeldan and Köse 2000; Cizre-Sakalliglu and Yeldan 2000; and Türel 1999). As one of the major indicators of the (functional) distribution of income, profit margins in fact followed an upward trend, reaching $47 \%$ in 1994 from its average of $33.5 \%$ in $1989 . .^{6}$ In the meantime, the fiscal gap widened abruptly, and the PSBR as a ratio of the GDP rose to $10.1 \%$ in 1991 and to $12.1 \%$ in 1993.

Given these broad shifts in the macroeconomic environment, the 1989 policy-manoeuvre of capital account liberalization served as one of the major policy initiatives which sustained the culminating fiscal deficits of the 1990s. This policy manoeuvre paved the way for the injection of liquidity into the domestic economy in the form of short-term foreign capital (flows of "hot money"). Such inflows enabled the financing of accelerated public sector expenditures, on the one hand and provided relief from the increased pressures of aggregate demand on domestic markets through the falling costs of imports on the other. ${ }^{7}$

6. State Institute of Statistics, Manufacturing Industry Surveys. See also Voyvoda and Yeldan (1999), Köse and Yeldan (1998); Yentürk (1997), and Sahinkaya (1993) on the behaviour of the profit margins (mark-ups) under the Turkish structural adjustment episode.

7. See Özatay (1999), Onis and Baysan (1999); Balkan and Yeldan (1998); Selçuk (1997); Boratav, Türel and Yeldan (1996); Ekinci (1998); and Yentürk (1999) for an extensive discussion of the post-financial liberalization macroeconomic adjustments in Turkey. 
Erratic movements in the current account, a rising trade deficit (from 3.5\% of GNP in 1985-1988 to 6\% in 1990-1993), and a drastic deterioration of fiscal balances made the post-1989 populism financed by foreign capital inflows unsustainable. This prolonged instability reached its climax during the fourth quarter of 1993, when the currency appreciation and the consequent current account deficits rose to unprecedented levels. With the sudden drainage of short-term funds at the beginning of January 1994, imports dwindled by $15 \%$, GDP fell by $5.5 \%$, and the inflation rate soared to $106 \%$. Together with this contraction, the post-1994 crisis management gave rise to significant shifts in income distribution, and real wages in manufacturing declined by $36.3 \%$. Dollar-denominated wage costs also decreased substantially and enabled export earnings to rise. Turkey had, once again, switched back to a mode of surplus extraction whereby the export performance of industrial sectors depended on savings in wage costs. In fact, the disequilibrium could only have been accommodated by the massive (downward) flexibility displayed by the real remunerations of wages.

The post-1994 crisis management depended heavily on wage suppression and the re-invigoration of short-term foreign capital inflows. As real wages continued to decline, foreign capital inflows enabled the financing of the fiscal gap and the consequent current account deficit. The cost of these adjustments to the treasury, however, was the acceleration of the interest burden on its borrowing instruments. The average real rate of interest offered on government bonds increased to more than $30 \%$ in real terms after the 1994 crisis, and the costs of servicing the domestic public debt reached $10 \%$ of gross national income by $1996 .{ }^{8}$ Finally, the global deceleration following the Asian financial crisis began to hit the Turkish economy in August 1998 under the already adverse conditions of severe macroeconomic disequilibria, with accelerating fiscal and current account deficits, high inflation and unemployment, and increased social unrest.

Clearly, the inherent characteristics of the growth-crisis-adjustment cycles identified thus far have had quite different macroeconomic dynamics in operation. While the import substitutionist (1969-1976) legacy was based on the protectionist rents of a closed economy with an overvalued exchange rate, the export orientation phase (1980-1988) was driven by commodity trade liberalization and real depreciation under conditions of wage suppression. The post1989 financial liberalization completed the integration of the domestic

8. Interest costs on the domestic public debt are about $15 \%$ of the GDP at the time of writing (June 2000). 
economy with the global commodity and financial markets, and initiated a process of short-term foreign capital-led growth with abrupt mini-cycles of boom and bust throughout the 1990s.

Before we analyse these dynamics from the viewpoints of growth, accumulation and distribution, we will present our methodology.

\section{THE METHODOLOGY}

Most of the macroeconomic series can be decomposed into a cyclical, trend and noise component if the data frequency admits more than yearly intervals. Among the given decomposition measures, Blanchard and Fischer (1989) give a precise definition of the structural measure of the cyclical component and describe how it relates to various other non-structural measures. Beveridge and Nelson (1981), however, developed decomposition measures of trend and cycle based on long-horizon forecasts. Cochrane (1994) also suggests a forecast-based approach by using consumption as a measure of the trend in output. We chose to use the linear filtering methods developed by Hodrick and Prescott (1997 [hereafter, HP]) because it is one of the most well-known techniques in modern business cycle research. ${ }^{9}$ Hodrick and Prescott cast the problem as one of the minimization of the squared deviations from the underlying trend component of a given variable subject to a penalty parameter. Once the trend is observed, the business fluctuations are derived as cyclical deviations from this path, and become the object of investigation for characterizing the dynamic adjustment patterns of the macroeconomy. ${ }^{10}$

In this study, as suggested by Hodrick and Prescott (1997, p. 4), we view a $5 \%$ cyclical component to be moderately large, as is a $0.25 \%$ change in the trend growth rate of annual data. Therefore, in our analysis, $\lambda$ satisfies, $\left(\frac{\sigma_{c}}{\sigma_{\sigma}}\right)^{2}=\left(\frac{5}{1 / 4}\right)^{2}$ i.e., assumes a value of 400 .

9. However, when the HP filter is applied to persistent time series, the filter itself generates business cycle dynamics even if none are present in the original data (for a critical discussion of the HP filter see, Harvey and Jaeger [1991], Cogley and Nason [1995] and King and Rebelo [1993]).

10. More formally, the HP method of de-trending is summarized as follows:

Let $y_{t}, t=\{1, \ldots, T\}$ be the observed time series expressed in natural logarithms, with where $y_{t}=y_{t}^{G}+y_{t}^{C}$ where $y_{t}^{G}$ is the trend of this series, and $y_{t}^{C}$ denotes the cyclical components. To identify the two components, HP minimizes the variance of $y_{t}^{C}$ subject to a penalty, $\lambda$, for the second difference of the growth term of the following function:

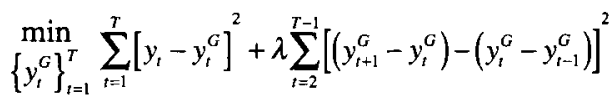


Figure 1. Cyclical GDP under alternative penalty parameter values

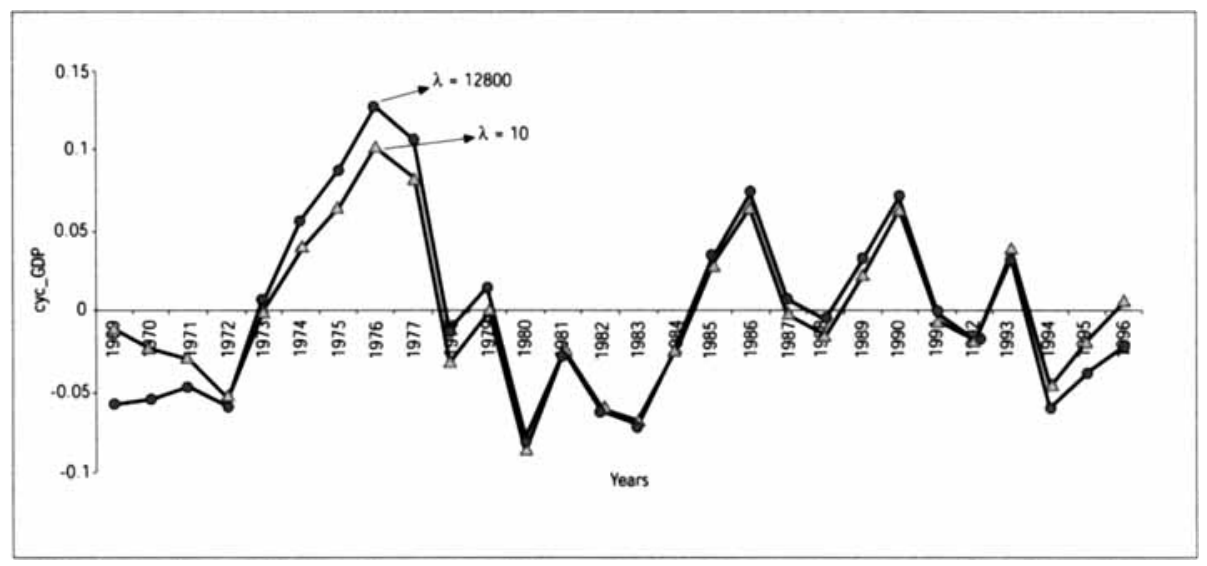

Figure 2. Manufacturing industry, large enterprises, cyclical wages

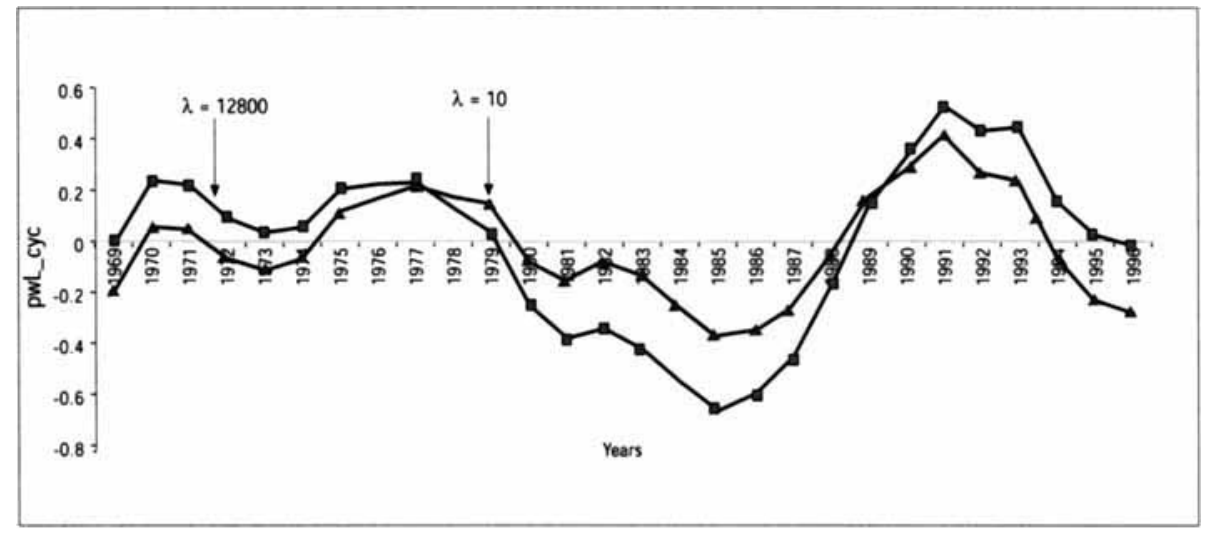

For an initial test of robustness, we also tried various other values of $\lambda$ such as $100,200,800,3,200,6,400$ and 12,800 to filter the data. In figures 1 and 2, we plot respectively, the cyclical component of GDP and real wage costs ( $\mathrm{W}^{\mathrm{R}}$ ) in the manufacturing industry large enterprises for two sufficiently distinct values of $\lambda(\lambda=100$ and $\lambda=12,800)$. The time path of the cyclical component of the series is observed to be quite robust under the relatively wide spectrum of $\lambda$ and match each other uniformly. With this observation, we will rely on our initial choice of $\lambda$ as set above, and implement the HP-filtering methodology on the Turkish time series data on key macroeconomic aggregates in the next section. 


\section{INVESTIGATING THE DYNAMIC ADJUSTMENTS IN MACRO-AGGREGATES}

Our aim in this section is to lay out the technical characterization of the cyclical phenomena in a developing global economy as studied in the contemporary literature on the macroeconomics of development and to establish links between the structural characteristics of the Turkish economy addressed in section II, given our technical results to be presented in this section. Thus, we attempt to point to a set of formal business cycle models for a developing economy, while searching for regularities in the historical data.

\section{A. VARIABILITY OF THE SERIES}

The first major issue in all historical accounts of the evolution of business cycles is volatility, both in relative terms with respect to GDP, and in absolute terms within the variable concerned. Shifts in volatility over time may reflect structural changes, institutional developments and the pursuit of different macro-management policies.

Table 2 presents the standard deviations, which we use as a measure of series' volatility. To structure our analysis, the variables we focus on are categorized under three headings: production and accumulation, distribution and prices, and internationalization.

The standard deviation $(\sigma)$ of each group of macro-variables is given under three sets of periodizations. The first column gives the standard deviation of the relevant variable throughout the whole time horizon, 1969-1997. We then split the time horizon into two: in the second column, we focus on the 19691982 period, which encompasses the import-substitution development and the structural adjustment phase; in the third column, we report the deviations relevant to the post-opening phase 1983-1996. In the next set of columns, we contrast the ratio of standard deviations with that of the GDP. Finally, as a further measure of the strength of association with real GDP, we use a simple OLS regression

$$
c_{j t}=\alpha_{j}+\sum_{i=-2}^{2} \beta_{j i} G D P_{t-i}
$$

for each of the series and report its $\mathrm{R}^{2}$ in the last column. 
Table 2. Statistical properties of selected macroeconomic aggregates

\begin{tabular}{|c|c|c|c|c|c|c|c|}
\hline & \multicolumn{3}{|c|}{ Standard deviation $(\sigma)$} & \multicolumn{3}{|c|}{$\sigma / \sigma_{G D P}$} & \multirow{2}{*}{$\frac{R^{2 b}}{1971-95}$} \\
\hline & 1967-97 & 1969-82 & 1983-97 & $1969-97$ & 1969-82 & $1983-97$ & \\
\hline \multicolumn{8}{|l|}{ Production and accumulation } \\
\hline GDP & 0.055 & 0.067 & 0.043 & - & - & - & - \\
\hline Industrial production & 0.075 & 0.070 & 0.082 & 1.374 & 1.046 & 1.903 & 0.56 \\
\hline Public sector investment & 0.160 & 0.148 & 0.175 & 2.907 & 2.203 & 4.037 & 0.55 \\
\hline Public manufacturing investment & 0.227 & 0.200 & 0.237 & 4.128 & 2.975 & 5.465 & 0.11 \\
\hline $\begin{array}{l}\text { Public energy and transportation } \\
\text { investment }\end{array}$ & 0.193 & 0.145 & 0.229 & 3.512 & 2.156 & 5.292 & 0.47 \\
\hline Private sector investment & 0.149 & 0.178 & 0.120 & 2.719 & 2.648 & 2.777 & 0.76 \\
\hline Private manufacturing investment & 0.174 & 0.219 & 0.118 & 3.171 & 3.252 & 2.729 & 0.59 \\
\hline $\begin{array}{l}\text { Private energy and transportation } \\
\text { investment }\end{array}$ & 0.172 & 0.192 & 0.141 & 3.140 & 2.861 & 3.243 & 0.25 \\
\hline Private housing investment & 0.256 & 0.241 & 0.279 & 4.663 & 3.582 & 6.436 & 0.52 \\
\hline $\mathrm{PSBR}^{\mathrm{a}}$ & 0.344 & 0.414 & 0.290 & 6.259 & 6.150 & 6.694 & 0.17 \\
\hline \multicolumn{8}{|l|}{ Distribution and prices } \\
\hline Real wage rate (public manufacturing) & 0.222 & 0.115 & 0.267 & 4.035 & 1.713 & 6.159 & 0.31 \\
\hline $\begin{array}{l}\text { Real wage rate (private } \\
\text { manufacturing small enterprise) }\end{array}$ & 0.127 & 0.116 & 0.138 & 2.304 & 1.729 & 3.190 & 0.39 \\
\hline Real wage rate (private & & & & & & & \\
\hline manufacturing large enterprise) & 0.175 & 0.147 & 0.196 & 3.195 & 2.186 & 4.531 & 0.34 \\
\hline CPI $(1969=1.00)$ & 0.164 & 0.215 & 0.117 & 2.987 & 3.189 & 2.704 & 0.77 \\
\hline Inflation rate of producer prices & 0.055 & 0.066 & 0.044 & 1.009 & 0.988 & 1.005 & 0.37 \\
\hline Inflation rate of consumer prices & 0.045 & 0.056 & 0.031 & 0.820 & 0.834 & 0.718 & 0.44 \\
\hline \multicolumn{8}{|l|}{ Internationalization } \\
\hline Exports (E) & 0.270 & 0.284 & 0.224 & 4.916 & 4.221 & 5.172 & 0.58 \\
\hline Imports (M) & 0.187 & 0.231 & 0.143 & 3.406 & 3.433 & 3.299 & 0.68 \\
\hline Trade deficit (M-E) & 0.320 & 0.361 & 0.267 & 5.821 & 5.361 & 6.157 & 0.35 \\
\hline Depreciation of exchange rate $(\mathrm{TI} / \$)$ & 0.182 & 0.185 & 0.159 & 3.321 & 2.753 & 3.659 & 0.47 \\
\hline
\end{tabular}

We find that the variability of real GDP is secularly less than the variability of its components, and we observe a general rise in the variability of the macro aggregates over the post-reform era when the economy is opened up. ${ }^{11} \mathrm{~A}$ Keynesian view, emphasizing the demand shocks, would argue that with relative stability in prices and exchange rates, output deviates from its long-run path more than it does in the 1983-1997 period, during when the economy experienced continued permanent inflation along with floating exchange

11. The issue of whether an opening up of the commodity and financial markets leads to more volatility in the economy is controversial in the business cycle literature. See Backus and Kehoe (1992) and Romer $(1986,1989)$. The common tendency is that shifting from a fixed exchange rate to a floating exchange rate regime or shifting to open capital markets should lead to more volatility (Devereux 1997; Basu and Taylor 1999; Obstfeld and Taylor 1998). 
rates. ${ }^{12}$ However, the PSBR, foreign trade components and CPI experienced dampened fluctuations in the post- 1982 period, yet relative to real national output, vacillation of their cyclical movements nevertheless increased. Furthermore, the PSBR and public investments display relatively small $\mathrm{R}^{2}$ for equation (1), indicating that the lead and lagged variations of GDP have little explanatory impact on the current period values of these variables.

There is a common fall in the volatility of private investment over the post1983 period both in aggregate terms and in its components destined for the manufacturing sector and the energy and transportation sector. The volatility of private housing investments, however, rose over the same period both in absolute terms and relative to GDP. The observed dampening of investment fluctuations in the traded sectors can be attributed primarily to the increased mobility of foreign capital under financial liberalization reforms. The increased openness of the financial sector seems to have enabled domestic investors to spread risk across capital markets and to get rid of the autarchic tendencies which tend to exacerbate the economic shocks. ${ }^{13}$

However, the unregulated in- and out-flows of speculative foreign capital can also be regarded as a major source of potential disequilibria, unleashing severe repercussions on exchange rates and the foreign trade components (see, for example, recent debates provided by Adelman 2000; Tobin 2000; Stiglitz 2000; Rodrik 2000; and the country episodes provided in UNCTAD 1999). The adverse consequences of the arbitrage-seeking, short-term, speculative capital flows would probably be more pronounced in the context of the relatively shallow asset markets of indigenous developing economies, increasing their fragility and leading to the deterioration of their macro-economic fundamentals. In this sense, it can be argued in the Turkish situation that increased capital mobility seems to have helped dampen volatility of investment patterns in the traded sectors at the expense of the increased volatility of the remaining macro-aggregates and wages, in particular.

12. The Ball, Mankiw and Romer (1988) model constructed in the New Keynesian tradition shows that firms in high-inflation countries change prices more frequently. Thus, countries with high mean inflation should have less persistent deviations of output from trend - a linking of nominal and real variables.

13. This view is also expressed in Basu and Taylor (1999). 


\section{B. THE BUSINESS CYCLE FACTS}

We now turn our attention to patterns of the business cycle as reflected in the behaviour of the de-trended movements (cyclical variations) of our macro aggregates. We use the operational definition of business cycle as commonly used in the literature to "describe related fluctuations in a wide range of economic activities" (Backus and Kehoe 1992, p. 873). Accordingly, we report on the pattern of correlation between fluctuations of real GDP and those of other macro-aggregates, and try to interpret them using different perspectives on business cycle modeling on the basis of phases of macroeconomic adjustments in Turkey, which we have summarized in section II. Our results are shown in table 3 . The table reports the cross-correlation coefficients between the cyclical deviations of real GDP at time period $t$ and the cyclical deviations of the relevant macro-variable. Values under column $t$ yield the contemporaneous cross-correlation coefficients. Values in columns $t-i$ and $t+i$ (with $i \in\{1,2\}$ ) give, respectively, the lead and lag correlations. A positive value indicates that the series is pro-cyclical; a negative value indicates that it is counter-cyclical. In other words, a relatively large value appearing under columns $t \pm i$ indicates that a series tends to lead or lag the cycle by $i$ years.

The results in table 3 show that industrial production peaks at currentperiod GDP. Investment aggregates have strong contemporaneous and lagged cross-correlation coefficients. However, this correlation is observed to be much stronger in the autarchic import-substitutionist period (1969-1979) than in the post- 1983 open economy era. Here again, one might argue that the buffer effect of foreign capital movements on investments lessens their response to booms and busts of the latter period.

We also find that correlations of the price inflation indicators suggest a mixed pattern. While the variations in the level of prices (the consumer price index [CPI]) depict strong negative correlations both contemporaneously and non-contemporaneously, the inflation rate as measured by log differences of the indexes of consumer and producer prices reveal non-conclusive trends. Even though all three measures of the price variations show a negative contemporaneous correlation, the lagged values of the inflation of consumer prices reveal a positive correlation with GDP, while the correlations of the lagged values of producer price inflation diminish sharply. Furthermore, the one-period lead values of the inflation rates of both consumer and producer prices across the two sub-periods are asymetric. While the leads of both inflation rates are countercyclical for the 1969-1982 interval, they are pro-cyclical for the post-reform 1983-1997 period. 
Table 3. Correlation coefficients of macro-aggregates with the GDP (\%)

\begin{tabular}{|c|c|c|c|c|c|c|c|c|c|c|c|}
\hline \multirow[b]{3}{*}{ Variable, C } & \multicolumn{11}{|c|}{ Cross-correlation between CDP ot $t$ and $C$ at } \\
\hline & \multicolumn{5}{|c|}{$1969-97$} & \multicolumn{3}{|c|}{$1969-82$} & \multicolumn{3}{|c|}{$1983-97$} \\
\hline & $t-2$ & $t-1$ & $\mathbf{t}$ & $t+1$ & $t+2$ & $t-1$ & $t$ & $t+1$ & $t-1$ & $\mathbf{t}$ & $t+1$ \\
\hline Industrial production & 18.69 & 25.04 & 71.15 & 33.57 & 28.31 & 35.72 & 78.99 & 21.90 & 15.04 & 69.48 & 52.93 \\
\hline $\begin{array}{l}\text { Public sector } \\
\text { investment } \\
\text { Public manufacturing }\end{array}$ & -9.73 & 25.41 & 68.36 & 54.85 & 24.55 & 28.12 & 79.26 & 72.88 & 24.13 & 62.88 & 40.22 \\
\hline $\begin{array}{l}\text { Public manufacturing } \\
\text { investment } \\
\text { Public energy and }\end{array}$ & -15.82 & 4.90 & 13.71 & -2.80 & 6.60 & 3.17 & 21.82 & 21.36 & 5.92 & 4.53 & -30.73 \\
\hline $\begin{array}{l}\text { transportation } \\
\text { investment } \\
\text { Private sector }\end{array}$ & 5.75 & 31.66 & 65.58 & 50.85 & 18.93 & 41.81 & 87.9 & 73.52 & 28.53 & 61.98 & 44.30 \\
\hline $\begin{array}{l}\text { investment } \\
\text { Private manufacturing }\end{array}$ & 19.30 & 38.12 & 67.67 & 69.72 & 59.05 & 57.52 & 80.55 & 80.82 & 8.51 & 41.62 & 40.98 \\
\hline $\begin{array}{l}\text { investment } \\
\text { Private energy and }\end{array}$ & 28.89 & 43.65 & 68.26 & 59.67 & 25.81 & 73.20 & 84.63 & 78.57 & -27.70 & 29.39 & 9.56 \\
\hline $\begin{array}{l}\text { transportation } \\
\text { investment } \\
\text { Private housing }\end{array}$ & 27.33 & 37.10 & 44.90 & 20.43 & 3.77 & 60.02 & 92.05 & 51.44 & -8.85 & -42.81 & -26.37 \\
\hline $\begin{array}{l}\text { investment } \\
\text { Real wage rate (publit }\end{array}$ & $i^{-5.11}$ & 9.50 & 37.70 & 55.90 & 66.31 & 3.78 & 36.88 & 63.42 & 15.69 & 42.21 & 47.29 \\
\hline $\begin{array}{l}\text { manufacturing) } \\
\text { Real wage rate (privat } \\
\text { manufacturing }\end{array}$ & -46.99 & -23.71 & 4.45 & 26.21 & 34.98 & -17.54 & 25.5 & 58.61 & -37.26 & -9.52 & 10.43 \\
\hline $\begin{array}{l}\text { Small enterprise) } \\
\text { Real wage rate (privat } \\
\text { manufacturing }\end{array}$ & -17.19 & 3.15 & 43.32 & 47.62 & 51.28 & 17.74 & 73.55 & 77.21 & -14.8 & 11.52 & 17.68 \\
\hline $\begin{array}{l}\text { large enterprise) } \\
\text { Exports (E) } \\
\text { Imports }(M) \\
\text { Trade deficit }(M-E) \\
\text { Depreciation of }\end{array}$ & $\begin{array}{r}-25.60 \\
48.15 \\
61.41 \\
22.46\end{array}$ & $\begin{array}{l}-0.01 \\
26.11 \\
52.13 \\
32.85\end{array}$ & $\begin{array}{r}36.98 \\
-16.49 \\
31.45 \\
52.15\end{array}$ & $\begin{array}{r}42.97 \\
-43.99 \\
-14.42 \\
13.14\end{array}$ & $\begin{array}{r}42.06 \\
-63.92 \\
-60.50 \\
-20.74\end{array}$ & $\begin{array}{l}26.16 \\
30.69 \\
66.03 \\
58.82\end{array}$ & $\begin{array}{r}70.69 \\
-13.36 \\
45.15 \\
66.91\end{array}$ & $\begin{array}{r}80.88 \\
-54.76 \\
2.56 \\
42.83\end{array}$ & $\begin{array}{r}-30.69 \\
26.61 \\
19.66 \\
-16.73\end{array}$ & $\begin{array}{r}6.65 \\
-21.54 \\
-0.41 \\
31.75\end{array}$ & $\begin{array}{r}13.17 \\
-26.78 \\
-53.28 \\
-39.06\end{array}$ \\
\hline $\begin{array}{l}\text { Uepreclation of } \\
\text { exchange rate }(\mathrm{L} / \mathbf{s}) \\
\text { PSBR } \\
\text { CPI }(1969=1.00)\end{array}$ & $\begin{array}{r}42.57 \\
-6.53 \\
-28.60\end{array}$ & $\begin{array}{r}13.32 \\
-14.19 \\
-48.33\end{array}$ & $\begin{array}{r}-18.47 \\
26.24 \\
-77.86\end{array}$ & $\begin{array}{r}-37.58 \\
26.15 \\
-69.85\end{array}$ & $\begin{array}{r}-60.21 \\
19.96 \\
-47.26\end{array}$ & $\begin{array}{r}4.14 \\
-11.96 \\
-52.45\end{array}$ & $\begin{array}{r}-19.79 \\
41.74 \\
-86.03\end{array}$ & $\begin{array}{r}-52.56 \\
21.98 \\
-80.32\end{array}$ & $\begin{array}{c}34.3 \\
-37.43 \\
-41.82\end{array}$ & $\begin{array}{r}-16.68 \\
8.70 \\
-59.84\end{array}$ & $\begin{array}{r}-23.56 \\
32.34 \\
-50.01\end{array}$ \\
\hline $\begin{array}{l}\text { Inflation rate of } \\
\text { producer prices } \\
\text { Inflation rate of }\end{array}$ & -25.15 & -18.67 & -50.75 & -0.09 & 0.13 & -44.48 & -52.55 & -3.61 & 29.66 & -51.46 & -22.79 \\
\hline consumer prices & -30.09 & -21.57 & -42.61 & 12.12 & 33.98 & -43.30 & -49.63 & 15.28 & 24.66 & -31.63 & 1.67 \\
\hline
\end{tabular}

a PSBR series cover 1975 orwards

How can one account for these realities the Turkish economy? On the one hand, the counter-cyclical pattern of movements of the Turkish CPI vis- $a$-vis real GDP seems to share the same attributes as reported by Backus and Kehoe (1992) in their study of the ten major industrial countries during the postwar period. Indeed, the counter-cyclical pattern of fluctuations of the price level $v i s-a-v i s$ real GDP is argued to be an underlying feature in many independent studies including those covering England (Blackburn and Ravn 1992), the US (Kydland and Prescott 1990) and Sweden (Englund et al. 1992), and is confirmed to be one of the most robust empirical regularities. On the other hand, the diverse patterns of the Turkish inflation rates also provide evidence to support Chadha and Prasad's (1994) and Agenor, McDermott and Prasad's (1999) warning about the importance of making a distinction between the 
level of prices and inflation when interpreting the behaviour of prices over the business cycle. In their study of the nature of the cyclicality of prices during the business cycle in the postwar G-7 countries, Chadha and Prasad confirm the counter-cyclicality of the price level, yet find strong evidence that the inflation rate acts pro-cyclically fashion in their sample.

The central implication of the nature of the cyclicality of prices during the business cycle pertains to whether deviations in national output from its longterm trend originated from shocks to aggregate demand or to supply. If the fluctuations in output were primarily the result of demand shocks, prices would be expected to move pro-cyclically; if, however, fluctuations in output were due to supply or technology shocks, prices would be expected to move counter-cyclically. It is now a generally accepted feature of price movements that short-term fluctuations in output are mostly associated with shocks to components of aggregate demand, whereas long-term fluctuations are mostly associated with shifts in aggregate supply (see, for example, Blanchard and Quah 1989).

Contrasted over the whole sample period, our results reveal a general counter-cyclical pattern, suggesting the importance of supply shocks in regulating the behaviour of prices with the current period GDP. However, the lead values of the consumer and producer inflation rates seem to have undergone a structural change in their characteristic nature across the 1969-1982 versus the post-reform 1983-1997 period. As far as the inflation rates are concerned, prices seem to have led the cycle counter-cyclically during 1969-1982 but procyclically during 1983-1997, suggesting the relative importance of supply shocks in the former and demand shocks in the latter. ${ }^{14}$

One of the most striking results that emerges from table 3 pertains to the behaviour of public investment, and that of the PSBR, in particular. Both the current and the one-period lagged public investment fluctuations are significantly correlated with the real GDP. Although this finding hints at the presence of crowding-out effects of public investments on real national product, we caution the reader against this interpretation and see this positive association as being related to the demand-pull effects of public expenditures on the GDP. The expected result toward a crowding-out relationship would warrant a positive correlation between two or three years lagged public investments

14. The mixed nature of the behaviour of prices is further observed when the contrast is made with correlations of real wages. In table 5 , we document that the cyclical variations in the private manufacturing real wage rates and consumer and producer price inflation yield unconclusive correlations over the 1983-1997 interval. Furthermore, one can trace no evidence that the deviations of the CPI lag the real wage movements systematically. 
and GDP, which we are unable to sustain given the short duration of our available sample periods. ${ }^{15}$ Nevertheless, our independent calculations reveal that private and public investments both disclose relatively strong pro-cyclical behaviour between $t-2$ and $t+2$ time intervals at the rates of $30.3 \%, 46.1 \%$, $40.5 \%, 30.3 \%$ and $11.6 \%$, respectively.

One can further point to striking differences in the behaviour of the components of investment aggregates along with the real GDP. While public manufacturing investments have rather weak correlations with domestic output, public investments in energy, and transport and telecommunications reveal relatively strong pro-cyclicality. The relative strength of this positive association seems to have been weakened in the 1983-1997 period, however, as the magnitudes of correlation coefficients tend to diminish in value. The same applies to private manufacturing investments and to energy, telecommunication and transport investments supporting our initial comments in section I, where we underlined an overall non-conformity between the accumulation patterns and growth targets based on export orientation. This assessment is further strengthened by our observations that the one-period lead values of private investments in housing have relatively weak correlations, yet they disclose significantly strong lagged co-movements. This result suggests that housing investments tend to lag the cycle in the Turkish economy, rather than being a source of aggregate demand. The asymmetric nature of the behaviour of private housing investments in comparison with manufacturing and energy and transportation investments (both public and private) underlines our earlier remark that the main duality of the Turkish accumulation patterns lies in the allocation of non-traded housing versus productive sectors rather than in public versus private investments.

The characteristic pattern of public expenditures is further studied in table 4 , with focus on the behaviour of PSBR. Table 4 presents the cross-correlation coefficients of current period PSBR with the lead and lag behaviour of selected macro-variables. We categorize the observed relationship in two sub-periods, partitioned by the strategic step of capital account deregulation which took place in 1988-1989. As mentioned in section I, the government's mode of financing the fiscal gap went a structural change in 1988-1989, with a switch from monetization to securitization of the domestic debt by way of newly introduced financial instruments. We take stock of this account by applying our de-trending procedure separately under all three periodizations in table 4 . The exercise in table 4 is carried out on the behaviour of the PSBR rather than

15. We are grateful to an anonymous referee for identifying to us this interpretation. 
Table 4. Public sector and selected macro-variables, correlation coefficients

\begin{tabular}{|c|c|c|c|c|c|c|c|c|c|c|c|}
\hline \multirow[b]{3}{*}{ Variable, C } & \multicolumn{11}{|c|}{ Cross-correlation between PSBR at $t$ and $C$ at } \\
\hline & \multicolumn{5}{|c|}{ 1975-97 } & \multicolumn{3}{|c|}{$1975-87$} & \multicolumn{3}{|c|}{ 1988-97 } \\
\hline & $t-2$ & $t-1$ & $\mathbf{t}$ & $t+1$ & $t+2$ & $t-1$ & $\mathbf{t}$ & $t+1$ & $t-1$ & $\mathbf{t}$ & $t+1$ \\
\hline $\begin{array}{l}\text { GDP } \\
\text { Private Sector }\end{array}$ & 19.96 & 27.90 & 26.24 & -12.66 & -6.53 & 18.67 & 18.78 & -10.93 & 46.30 & 39.47 & -32.90 \\
\hline $\begin{array}{l}\text { Investment } \\
\text { Private }\end{array}$ & 26.24 & 28.40 & 38.32 & 23.55 & 3.36 & 40.30 & 48.38 & 25.57 & -36.54 & -10.11 & -2.78 \\
\hline $\begin{array}{l}\text { Private Manufacturing } \\
\text { Invest. } \\
\text { Private Energy \& Iran }\end{array}$ & 17.20 & 9.26 & 14.42 & 24.53 & 11.30 & 24.29 & 16.91 & 28.84 & -30.26 & 1.48 & 4.68 \\
\hline $\begin{array}{l}\text { Invest. } \\
\text { Private Housing }\end{array}$ & -10.84 & 4.20 & 1.56 & -11.69 & 4.83 & 11.96 & 7.88 & -17.80 & 12.81 & 3.08 & -7.89 \\
\hline Invest. & 22.96 & 33.33 & 45.37 & 19.79 & 5.15 & 45.40 & 56.70 & 20.10 & -16.49 & 6.63 & 7.88 \\
\hline $\begin{array}{l}\text { CPI }(1969=1.00) \\
\text { Inflation Rate of }\end{array}$ & -22.86 & -16.40 & -14.00 & 8.56 & 8.86 & 1.24 & 10.46 & 37.06 & -31.19 & -44.98 & -27.75 \\
\hline $\begin{array}{l}\text { Producer Prices } \\
\text { Inflation Rate of }\end{array}$ & -14.14 & -19.66 & 10.59 & 32.14 & 0.35 & -9.42 & 35.92 & 36.73 & -47.68 & -54.36 & 26.20 \\
\hline Consumer Prices & 0.63 & -7.71 & 8.45 & 35.54 & 2.32 & 3.30 & 26.27 & 39.65 & -59.15 & -61.71 & 36.20 \\
\hline
\end{tabular}

on public investments because it is mostly the former that inflicts a non-stabilizing pressure on the domestic economy.

Our results suggest that the PSBR is negatively correlated with the cyclical deviations of lagged real output. Furthermore, the algebraic magnitude of the negative correlations intensifies under the 1988-1997 periodization for the one-period ahead (lagged) values of the real GDP. The PSBR displays procyclical movements with private investments in manufacturing and in housing during 1975-1987. However, such positive associations diminish and, in fact, change in sign during the post-financial liberalization of 1988-1997. Although our methodology precludes us from making any formal remarks on the nature of this relationship, it is difficult to resist extrapolating on the source of this shift. Generally speaking, one can conjecture that this shift toward the diminishing and/or counter-cyclical nature of correlations between the PSBR and the one-period ahead deviations in real output and components of private investment has more to do with the changing mode of financing the fiscal deficit after 1989. As the treasury shifted toward domestic borrowings rather than expansionary monetization, financing of the PSBR seems to generate more of a crowding-out, or at best, neutral effect on national output.

One hypothesis implicit in Selçuk (1997) is that, with an increasing fiscal gap in the 1990s, private agents effectively found themselves with an additional binding constraint on the realization of their foreign borrowing plans. As the fiscal gap widened, the government sought to rely on foreign finance, squeezing out the optimal plans on private consumption smoothing. As the 
major expenditure category of the national product, the increased constriction of private consumption in the post- 1989 period seems to have played a direct role in transmitting the perils of the widening fiscal gap over to the national output.

Even though many of these arguments rely on conjectural numerical evidence, they seem to reflect the changing nature of the dynamics between public expenditures and components of the GDP. This contrasts starkly with the findings for the developed economies, where government purchases are reported to behave almost orthogonally to output and show no sign of a phase shift in either direction (See, for example, Backus and Kehoe 1992; Blackburn and Ravn 1992). This contrast can probably be explained by the sharp swings of the policy regimes as reported throughout the time span of our analysis.

Another interesting observation about the PSBR pertains the nature of its correlations with variations in prices. The contemporaneous correlations among both consumer and producer price inflation and PSBR are positive for 1975-1987. These findings are parallel to Metin's findings (1995 and 1998) on Turkish patterns of inflation over the broader period 1950-1987, and also conform to the prognostications of the theoretical literature on hyper-inflation (see, for example, Sargent 1982; Dornbusch and Fischer 1986). Metin argues that the most important determinant of inflation in Turkey was the central government deficit and that the fiscal expansion was indeed inflationary over 1950-1987. She also finds evidence that increases in the public sector deficit resulted in a short-run increase in GNP which tended to lower inflation. As for the post-1989 phase, however, the positive association between our inflation measures and the PSBR disappears, and these series display strong contemporaneous counter-cyclical movements over the post-1989 period, with a relatively weaker correlation with the one-period lagged inflation rates. This outcome suggests that the nature of financing of the PSBR over the post1989 period has had deflationary consequences on the price level, and that the so-called destabilizing consequences of the fiscal gap reveal themselves not through the cyclical component of price inflation but through inertial expectations built over a series of failed attempts in reforming the state apparatus (Selçuk and Rantanen 1996; Özatay 1999). In fact, our exercise in filtering the variations of consumer prices documents that the amplitude of the cyclical component of CPI is extremely low and is almost at par with its (inertial) trend. (See also Cizre-Sakallıglu and Yeldan 1999; Uçer 1999; Ózatay 2000; and Uygur 1999). 


\section{DYNAMIC ADJUSTMENTS OF WAGES AND DISTRIBUTIVE VARIABLES}

We now turn our attention to the patterns of wage costs, average labour productivity and macro-aggregates. Our findings in table 3 suggest that real GDP has relatively modest counter-cyclical correlations with the two-year lead of real wages. The relative strength of this effect is stronger for public manufacturing wages $(-46.9 \%)$, and weaker for private manufacturing wages $(-17.9 \%$ to $+25.6 \%$ ). Real wages have positive correlations both contemporaneously and in their lagged movements. The most important observation about the movement between real wages and real GDP pertains to the asymmetry across the import-substitutionist, 1969-1982, and the post-structural adjustment, 1983-1997 episodes. Real wage rates in private manufacturing display very strong pro-cyclical contemporaneous relationship with real output during the 1969-1982 interval (73.5\% for small manufacturing firms and $70.7 \%$ for large enterprises). This changes abruptly in the post- 1983 period. The contemporaneous correlation of private manufacturing wages with the real GDP falls sharply to less than $10 \%$, while public manufacturing wages display a weak counter-cyclicality. The one-period lagged real wages now also display stronger counter-cyclicality.

We investigate the dynamics of the cyclical deviations of real wage costs with the relevant macro-aggregates further in table 5 . Here, the variable of interest on the column heading is the real wage costs in large private enterprises, and the entries yield the correlation coefficients of the cyclical deviations of macro-variables with the order of series adjusted to span $t-2$ to $t+2$ periods around the $\mathrm{W}^{\mathrm{R}}$ at time $t$.

Another variable of interest is the average labour productivity in the manufacturing industry. Our findings suggest quite a modest set of correlation coefficients between both lead and lagged values of labour productivity and real wage costs in private manufacturing. The cycle seems to peak at the oneperiod lagged value of the average labour productivity, though still at a modest $52.1 \%$. Thus, over the cycle, deviations of real wage costs and average labour productivity seem to be correlated only about half the time in large private manufacturing enterprises. This is in contrast to the results documented on the business cycle studies in the US and other industrialized OECD economies. For example, Blackburn and Ravn (1992) report a generally strong pro-cyclical relationship between productivity and wages in England, and state that both tend to move contemporaneously with the cycle. This contradistinction in our case is probably a result of the wide swings in the real wage cycle in Turkey and abrupt regime changes in the variables that most affect labour remunerations. 
Table 5. Correlation of macro-aggregates with the private manufacturing industry real wages $(\%)$

\begin{tabular}{|c|c|c|c|c|c|c|c|c|c|c|c|}
\hline \multirow[b]{3}{*}{ Variable, $\mathrm{C}$} & \multicolumn{11}{|c|}{ Cross-correlation between wages at $t$ and $C$ at } \\
\hline & \multicolumn{5}{|c|}{ 1969-97 } & \multicolumn{3}{|c|}{$1969-82$} & \multicolumn{3}{|c|}{$1983-97$} \\
\hline & $\mathbf{t - 2}$ & $\mathbf{t - 1}$ & $\mathbf{t}$ & $t+1$ & $\mathbf{t + 2}$ & $t-1$ & $\mathbf{t}$ & $t+1$ & $t-1$ & $\mathbf{t}$ & $t+1$ \\
\hline $\begin{array}{l}\text { Industrial production } \\
\text { Public sector }\end{array}$ & 43.13 & 25.13 & 4.40 & -35.13 & -48.24 & 48.72 & 46.24 & -4.43 & 21.89 & -17.78 & -46.62 \\
\hline $\begin{array}{l}\text { investment } \\
\text { Public manufacturing }\end{array}$ & 2.60 & 17.20 & 23.34 & 1.20 & -23.58 & 80.33 & 81.77 & 45.65 & -16.18 & -7.60 & -4.18 \\
\hline $\begin{array}{l}\text { investment } \\
\text { Public energy and }\end{array}$ & -20.60 & 11.29 & 16.00 & 15.45 & 28.45 & 61.29 & 35.33 & 19.87 & -20.13 & -4.97 & -3.94 \\
\hline $\begin{array}{l}\text { transportation } \\
\text { investment } \\
\text { Private sector investm }\end{array}$ & $\underset{\text { nent }}{10.22}$ & 9.10 & 11.16 & -11.94 & -38.21 & 76.86 & 79.19 & 44.01 & -12.31 & 4.24 & -10.45 \\
\hline $\begin{array}{l}\text { Investment } \\
\text { Private manufacturing }\end{array}$ & 56.73 & 50.24 & 39.96 & 17.88 & 0.57 & 75.84 & 71.19 & 39.42 & 15.17 & 8.70 & $-4,36$ \\
\hline $\begin{array}{l}\text { investment } \\
\text { Private energy and }\end{array}$ & 35.33 & 46.46 & 44.61 & 27.18 & 7.09 & 85.03 & 69.50 & 24.23 & -14.76 & 16.42 & 20.85 \\
\hline $\begin{array}{l}\text { transportation } \\
\text { investment } \\
\text { Private housing }\end{array}$ & 6.20 & 31.96 & 42.79 & 33.33 & 8.88 & 79.37 & 75.52 & 18.47 & -19.37 & 7.49 & 20.27 \\
\hline $\begin{array}{l}\text { investment } \\
\text { Real wage rate }\end{array}$ & 48.59 & 30.06 & 22.01 & 11.50 & 6.24 & 19.40 & 43.72 & 51.39 & 22.96 & 9.35 & -5.43 \\
\hline $\begin{array}{l}\text { manufacturing) } \\
\text { Real wage rate } \\
\text { (private manufacturin }\end{array}$ & 16.32 & 56.51 & 89.53 & 85.82 & 61.88 & 36.91 & 80.06 & 82.42 & 52.09 & 94.03 & 87.71 \\
\hline $\begin{array}{l}\text { small enterprise) } \\
\text { Exports }(\mathrm{E}) \\
\text { Imports }(M) \\
\text { Trade deficit (M-E) }\end{array}$ & $\begin{array}{r}34.99 \\
-24.74 \\
13.87 \\
33.34\end{array}$ & $\begin{array}{r}68.90 \\
-49.88 \\
-5.38 \\
40.48\end{array}$ & $\begin{array}{r}90.19 \\
-67.27 \\
-31.68 \\
35.28\end{array}$ & $\begin{array}{r}69.36 \\
-70.81 \\
-48.23 \\
9.22\end{array}$ & $\begin{array}{r}25.15 \\
-59.07 \\
-45.79 \\
0.46\end{array}$ & $\begin{array}{r}54.93 \\
-17.16 \\
52.05 \\
77.00\end{array}$ & $\begin{array}{r}81.08 \\
-45.59 \\
-7.74 \\
28.12\end{array}$ & $\begin{array}{r}70.54 \\
-82.71 \\
-52.91 \\
-3.36\end{array}$ & $\begin{array}{r}70.09 \\
-61.16 \\
-64.82 \\
-1.51\end{array}$ & $\begin{array}{r}95.95 \\
-86.55 \\
-68.57 \\
34.07\end{array}$ & $\begin{array}{r}71.76 \\
-59.05 \\
-55.98 \\
3.75\end{array}$ \\
\hline $\begin{array}{l}\text { Depreciation of } \\
\text { exchange rate }(\mathrm{TL} / \$) \\
\mathrm{PSBR}^{\mathrm{a}} \\
\text { CPI }(1969=1.00) \\
\text { Inflation rate of }\end{array}$ & $\begin{array}{r}-35.91 \\
37.63 \\
-35.20\end{array}$ & $\begin{array}{r}-62.46 \\
42.94 \\
-37.85\end{array}$ & $\begin{array}{r}-73.98 \\
50.55 \\
-38.88\end{array}$ & $\begin{array}{r}-64.74 \\
45.03 \\
-14.42\end{array}$ & $\begin{array}{r}-45.85 \\
17.16 \\
17.63\end{array}$ & $\begin{array}{r}-41.19 \\
1.57 \\
-79.99\end{array}$ & $\begin{array}{r}-62.61 \\
2.31 \\
-87.83\end{array}$ & $\begin{array}{r}-81.74 \\
16.36 \\
-55.07\end{array}$ & $\begin{array}{r}-71.77 \\
63.22 \\
-4.95\end{array}$ & $\begin{array}{r}-83.46 \\
78.72 \\
5.70\end{array}$ & $\begin{array}{r}-48.68 \\
53.47 \\
1.28\end{array}$ \\
\hline $\begin{array}{l}\text { producer prices } \\
\text { Inflation rate of }\end{array}$ & 0.05 & -0.06 & -12.14 & 24.54 & 46.00 & -40.71 & -28.71 & 25.89 & 4.42 & -22.48 & 11.55 \\
\hline consumer prices & 11.15 & -1.63 & -6.49 & 30.79 & 48.89 & -35.90 & -19.16 & 42.94 & 12.00 & -21.08 & 9.19 \\
\hline
\end{tabular}

PSBR series cover 1975 orwards

Figures $3 \mathrm{a}$ and $3 \mathrm{~b}$ illustrate this line of reasoning clearly. In fig. $3 \mathrm{a}$, we document the trend in real average labour productivity in manufacturing industry and the historically realized values over a broader time horizon, 1950-97. The units on the $y$-axis are in real 1963 Turkish lira prices in log scale. In fig. $3 \mathrm{~b}$ we provide the same information for real wages in large private manufacturing enterprises. The contrast of the two pictures is striking. The trend of average labour productivity follows a secular rise for the whole cycle, with an average annual growth rate of $3.8 \%$ for the period $1950-1997$. This is to be contrasted with the trend in the real wage rate shown in figure $3 \mathrm{~b}$. Real wages fluctuate on a generally increasing path until the mid-1970s, decelerating between 1980 and 1988 and recovering after 1989. The observed recovery in real wages is clearly the end result of the post-1989 populism which enabled sharp increases in real wages between 1989 and 1993, as explained in section I. 
Figure 3a. Real average labour productivity in large private

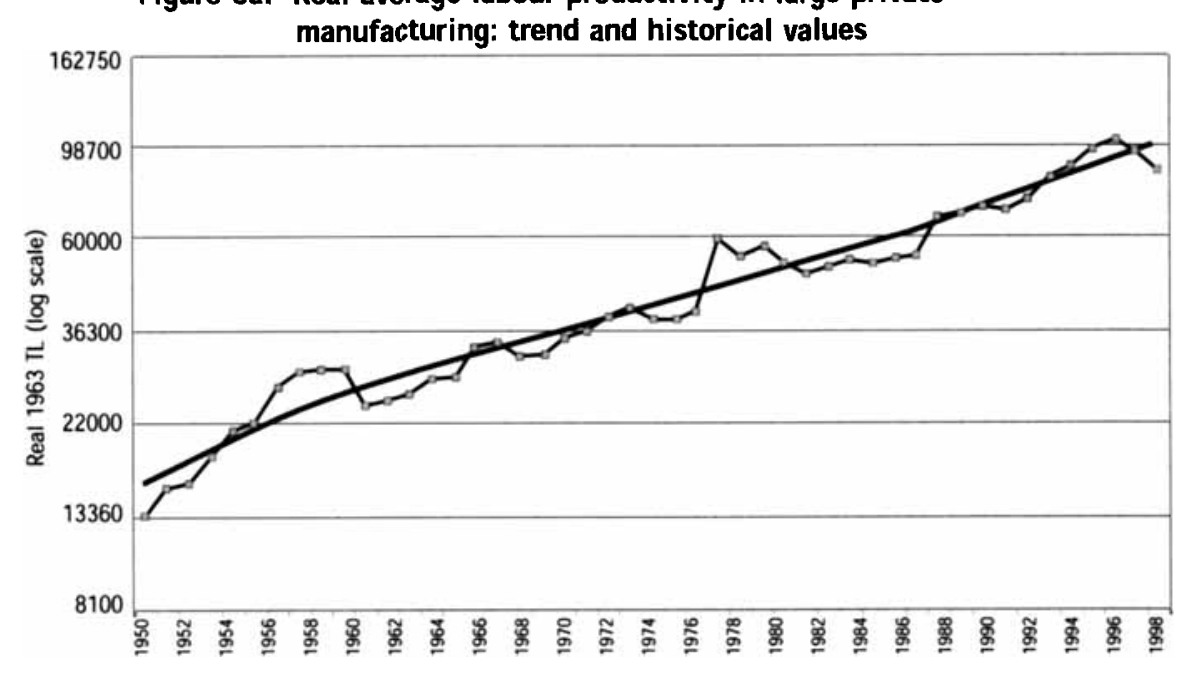

Figure 3b. Real wages in large private manufacturing: trend and historical values

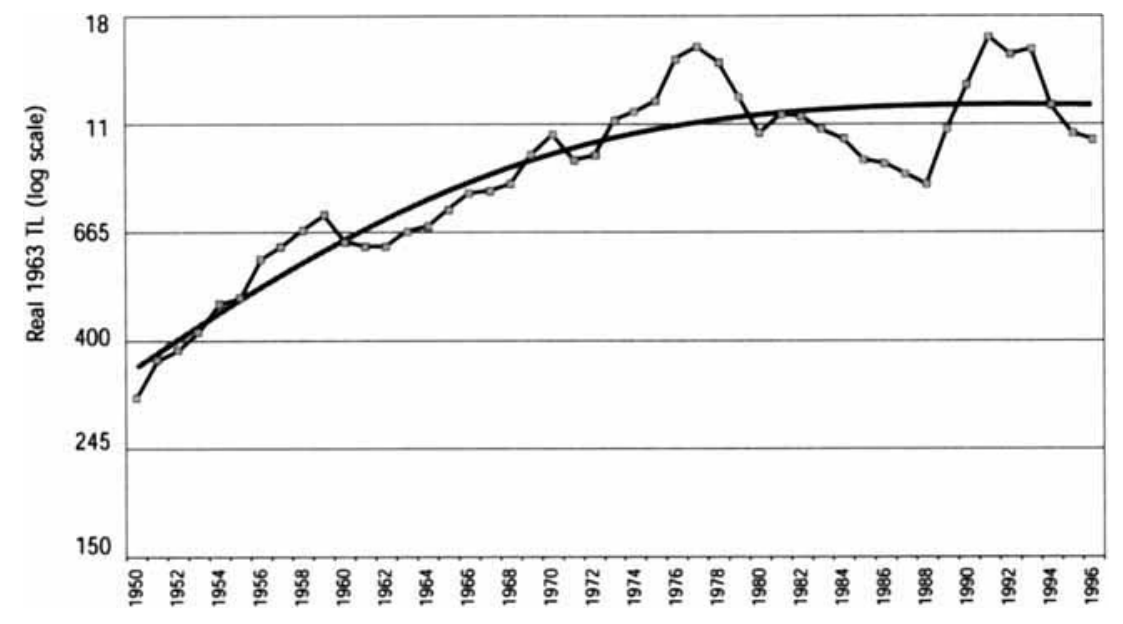

It can be argued that the post-1989 upswing in manufacturing real wages was in fact in line with the real average labour productivity as far as the long trends of the two series are concerned. 16

16. See Boratav (1991) for a narrative support of this claim. 
The fluctuations of the real wage trend consequently document the periodization of the overall political cycle in the Turkish labour markets. The fundamental characteristic of this cycle is the relatively weak connection between wage remunerations and labour productivity in manufacturing industries. The trend path of real wages clearly breaks after 1979-1980, with the average trend of growth of real wages at $2.9 \%$ for $1950-1979$ falling sharply to $0.5 \%$ for 1980-1997.

The observed asymmetry between wage remunerations and real output across the import-substitutionist and outward-oriented intervals clearly underscore the changed nature of wage-labour in the manufacturing industries. During the autarchic and domestic demand-oriented import-substitutionist phase, wages tended to have a dual function, serving as a source of demand, as well as acting as a cost item. Given the oligopolistic profits and protectionist rents of an autarchic domestic market, industrialists were more receptive to a general rise in the wage bill. With the post- 1980 switch toward export orientation, however, the domestic market started to lose its function as the main source of aggregate demand, and wages came to be regarded only as a cost item. ${ }^{17}$ The sustained strong counter-cyclicality of real wages with both exports and currency depreciation can be interpreted as a further manifestation of these dynamics.

The nature of the cyclicality of wages has a long history in the literature and is important in distinguishing among alternative theories of the business cycle and their predictions (see Abraham and Haltiwanger 1995 for a thorough review). Models of the Keynesian genre typically posit short-run movements along a stable labour demand schedule and imply that real wages are countercyclical, while the equilibrium models of the real business cycle literature rely on technological shocks in their hypotheses on the pro-cyclical behaviour of real wages. The new-Keynesian and Structuralist macroeconomic models, however, underline the imperfectly competitive nature of the labour markets and the persistence of mark-up pricing in advancing pro-cyclical wages. ${ }^{18}$

17. In a series of general equilibrium models Wood (1994) and Minford, et al. (1997) generalize these trends over to the marginalization of the labour markets of the industrial North in the face of increased competition from the South. Singh (1999) is critical of the mechanisms advanced by Wood and argues that the chief constraints on faster OECD growth lie on the demand side, and that such constraints are not due to technological bottlenecks but mainly to institutional factors rooted in the process of post-financial liberalization and globalization of the unregulated capital flows.

18. See, for example, Taylor (1981) and Rotemberg and Woodford (1991) for this class of models. 
While the debate over the cyclicality of real wages is marred with inconclusive evidence and conflicting methodological issues, ${ }^{19}$ it is clear in the case of Turkey that the underlying characteristic of wage cyclicality has undergone a structural change over 1979-1980, breaking the generally positive association between wages and many other macro-aggregates, including average labour productivity. This assessment further signifies itself over the behaviour of investment categories across the two time intervals. Both public and private aggregate investments display strong pro-cyclical lead and contemporaneous movements with private manufacturing real wages in 1969-1982. Private investments in manufacturing and energy and transport have contemporaneous correlations reaching $69.5 \%$ and $75.5 \%$, respectively. Over the $1983-1997$ interval, the same correlations fall sharply to $16.4 \%$ and $7.5 \%$. Furthermore, the overall complementarity between both public and private investments and wages disappear and turn negative in this period.

These findings suggest that the presence of demand-induced effects of higher wages on manufacturing investments in the 1969-1982 period have been declining in the post-reform era. Although the averages of the broad time horizon (1969-1997) still suggest that real wages and investments have pro-cyclical co-movements over the cycle, this effect seems to be severely disrupted during the current stage of the Turkish economy.

Our findings can be contrasted with the results presented in Yentürk and Onaran (1999) who, using econometric methods within panel data analysis covering 26 sub-sectors of private manufacturing for 23 years, found evidence indicating that the response of investment to demand is much stronger than its response to the profit share. Based on their econometric findings, Yentürk and Onaran argue for the existence of a stagnationist pattern of accumulation and a wage-led growth regime in the Turkish manufacturing industries. Clearly, notwithstanding the methodological differences, our results generally concur with Yentürk and Onaran's findings for the pre-reform period.

\section{DYNAMIC ADJUSTMENTS OF THE FOREIGN TRADE MAGNITUDES}

Trade deficits are pro-cyclical and move contemporaneously with the real GDP. Qualitatively, this is also a feature shared by the US and other industrialized OECD economies. The individual behaviour of exports and imports,

19. Abraham and Haltiwanger (1995) point to the importance of the choice of alternative price deflators in deflating the nominal wages. They provide evidence, for instance, that the postwar US wages deflated by the consumer price index are more pro-cyclical than wages deflated by the producer price index. 
however, is quite different when contrasted with the results obtained for those countries. Merchandise exports indicate a counter-cyclical relationship with a two-year lag (see table 3). Two-year lead of exports have pro-cyclical, but relatively modest correlations with real national output. This unexpected and puzzling characteristic of the export cycle warrants an explanation. Our main line of reasoning is based on our earlier remarks about the rather weak character of merchandise exports and the post-1980 export promotion program, in general. The artifice of the export boom during the 1980s was sustained mainly by a generous export subsidization program, coupled with wage suppression. Furthermore, throughout the whole decade, export-oriented manufacturing was not apprehended by a sound investment program, and export flows were subject to erratic signals and wide swings in the unstable political relations among countries in the region. Under these conditions, export orientation was clearly loosely associated with the real production sphere of the domestic economy, and it should come as to no surprise to find weak and often contradictory effects of the cyclical component of exports.

The belligerence of the export orientation on labour remunerations is reflected clearly in our numerical findings. The results in table 5 suggest a strong counter-cyclical contemporaneous relationship between exports and manufacturing wages. In general, cyclical deviations of exports do have a counter-cyclical pattern against manufacturing real wages under all time horizons considered. As discussed earlier, this phenomenon is attributable to the changing nature of wages toward a "cost item" rather than a component of domestic demand under the phase of export-oriented growth.

In terms of imports, there is a dual pattern. Real GDP is negatively correlated with two-period lead of imports but is positively related with their twoperiod lag. In particular the contemporaneous behaviour of imports is relatively weak. This is in stark contrast to the reported behaviour of imports in the US and England. The observed pro-cyclical lead pattern signifies the complementary character of merchandise imports. This observation, however, does not explain the shift toward the counter-cyclical nature of the lagged series, indicative of the existence of third party relationships affecting the overall cycle to which our decomposition exercise is not equipped to address.

All these propositions can be studied from a different angle which takes into account nominal exchange rate movements. In table 6 , we study the cross-correlations of the cyclical deviations of the exchange rate and selected variables under different policy regimes. Currency depreciation has a countercyclical correlation with the two-year lead of the GDP over the whole 1969-1996 
Table 6. Foreign sector and selected macro-variables, correlation coefficients (\%)

\begin{tabular}{|c|c|c|c|c|c|c|c|c|c|c|c|}
\hline \multirow[b]{3}{*}{ Variable, C } & \multicolumn{11}{|c|}{ Cross-correlation between exchange rate at $t$ and $C$ at } \\
\hline & \multicolumn{5}{|c|}{ 1969-97 } & \multicolumn{3}{|c|}{ 1969-79 } & \multicolumn{3}{|c|}{ 1980-97 } \\
\hline & $t-2$ & $t-1$ & $\mathbf{t}$ & $t+1$ & $t+2$ & $t-1$ & $\mathbf{t}$ & $t+1$ & $t-1$ & $\mathbf{t}$ & $t+1$ \\
\hline $\begin{array}{l}\text { GOP } \\
\text { Exports } \\
\text { Imports } \\
\text { Trade Deficit } \\
\text { Real wage rate (public }\end{array}$ & $\begin{array}{r}-62.20 \\
40.84 \\
-2.67 \\
-34.06\end{array}$ & $\begin{array}{r}-39.79 \\
68.73 \\
33.05 \\
-19.37\end{array}$ & $\begin{array}{r}-18.47 \\
88.53 \\
49.88 \\
-26.71\end{array}$ & $\begin{array}{l}15.64 \\
72.67 \\
50.00 \\
-7.54\end{array}$ & $\begin{array}{l}44.65 \\
48.84 \\
37.17 \\
-5.38\end{array}$ & $\begin{array}{r}-67.19 \\
56.34 \\
-19.47 \\
-50.74\end{array}$ & $\begin{array}{r}-46.30 \\
86.00 \\
36.55 \\
-15.20\end{array}$ & $\begin{array}{l}-6.09 \\
88.83 \\
48.25 \\
-7.41\end{array}$ & $\begin{array}{r}-10.20 \\
74.24 \\
79.60 \\
18.35\end{array}$ & $\begin{array}{r}11.92 \\
89.28 \\
65.11 \\
-36.96\end{array}$ & $\begin{array}{r}44.22 \\
57.11 \\
55.40 \\
6.90\end{array}$ \\
\hline $\begin{array}{l}\text { manufacturing) } \\
\text { Real wage rate } \\
\text { (private manfacturin }\end{array}$ & -25.65 & -54.09 & -74.01 & -78.92 & -66.39 & -76.67 & -88.00 & -82.94 & -47.43 & -68.89 & -82.29 \\
\hline $\begin{array}{l}\text { small enterprise) } \\
\text { Real wage rate } \\
\text { (private manufacturi }\end{array}$ & -44.94 & -52.99 & -58.87 & -47.25 & -25.46 & -71.58 & -64.98 & -32.41 & -41.05 & -55.50 & -52.38 \\
\hline large enterprise) & -45.49 & -61.30 & -73.98 & -61.17 & -37.92 & -83.95 & -74.96 & -47.27 & -45.97 & -70.39 & -71.46 \\
\hline
\end{tabular}

time span. This contrasts strongly, however, across the two sub-periods. Under the import-substitutionist, domestic demand-oriented phase (1969-1979), this persists in qualitative terms, but under the outward orientation of the post- 1980 period, the counter-cyclical nature of the two correlations gives way to a pro-cyclical pattern with the one-year lagged values of the deviations of real GDP. ${ }^{20}$ The exchange rate does show a strong and robust pro-cyclical relationship with both the contemporaneous and lagged export cycles. Crosscorrelations of the trade deficit cycle with the exchange rate movement are rather weak but toward more of a leading counter-cyclical pattern.

Currency depreciation reveals strong lead and lagged counter-cyclical correlations with manufacturing real wages in the 1980-1997 period. Although it is difficult to make broad generalizations, the mechanics of this adjustment can be traced to the trade-off between wages and currency depreciation in the determination of total costs for the manufacturing industry. An increase in the rate of currency depreciation would call for a substitution effect between wage-labour and imported intermediates and an income effect on enterprises' aggregate wage fund. Given the mostly complementary nature of intermediate imports in gross output, it is plausible to expect that during periods of appreciation, the cost savings would be more easily translated into wage concessions, yet enterprises would be more reluctant to grant higher wages at times of increased import costs through devaluation. This relationship is studied at length in Yentürk (1997), Onaran (1999), Yeldan and Köse (1999),

20. Because of insufficient time series data, we have not carried our analysis to longer time intervals. 
and Boratav (1991) who found a significantly positive association between remunerations of wage-labour and exchange rate appreciation in the manufacturing industry.

\section{CONCLUSION}

In this paper, we attempted to present empirical evidence on the nature of the business cycles and dynamic macro-adjustments in the globalizing developing economy of Turkey. Using annual data for 1969-1997, we followed the nowseminal work of Hodrick and Prescott (1997) to decompose the time series of key macro-aggregates into a trend component with cyclical deviations around the trend. Our study of the statistical properties of the cyclical component of the macro aggregates reveals that although the Turkish economy shares most of the attributes of the business cycles of the developed world, it differs significantly in the behaviour of certain key variables.

Our results reveal a general rise in the relative variation of macro-aggregates against GDP during the post-structural adjustment phase of the 1980s and 1990s. The PSBR, foreign trade components and private manufacturing investments dampened their fluctuations as measured in terms of their respective standard deviation coefficients. We interpreted the reduced volatility of private investments in the traded sectors as a concomitant result of the increased mobility of foreign capital under financial liberalization reforms and argued that the increased capital mobility seems to have helped dampen the volatility of investment patterns in the traded sectors at the expense of the increased volatility of the remaining macro-aggregates, and wages, in particular. In this sense, we find supporting evidence that the change in capital mobility should be regarded as the most important factor affecting the business cycles.

Public investments in energy and transport revealed significant contemporaneous pro-cyclical behaviour with both real GDP and private investment, suggesting crowding-out attributes. However, the relative strength of this association seems to have weakened in the post-1983 structural adjustment reform era. We also found evidence that shocks to aggregate demand gained more importance during this period, indicating the increased need for attention toward demand-management policies, especially with respect to public expenditures. Furthermore, when we take into account the PSBR, we find that the significance of the crowding-out patterns and demand-pull characteristics is diminished and tends to be reversed for the 1988-1996 period - the completion of financial liberalization and capital account deregulation. This contrasts 
with the results reported for the industrialized economies of the OECD, where government purchases display no sign of a phase shift in either direction. Finally, the counter-cyclical behaviour of the PSBR indicates the need to reexamine the revenue sources and financing mechanisms of public expenditures in order to ensure that they do not exacerbate the economic fluctuations.

Manufacturing real wages in the private sector displayed relatively modest counter-cyclical correlations against real output, whereas lagged wages in small and large private manufacturing enterprises were pro-cyclical. In general, real wages in large private manufacturing enterprises generate relatively weak correlations with average labour productivity. In particular, the trend components of the two series display a negative relationship in 19801988 and reveal a comovement only after 1989, with significant real wage increases under the "new populism" of 1989-1991. Our results also reveal that the demand-induced characteristics of wage-led investment patterns in private manufacturing have been on a declining trend in the post-reform period; and that the mechanics of accumulation changed significantly in the Turkish economy of the 1990s.

Overall merchandise exports revealed a poor correlation coefficient with real GDP and a significant counter-cyclical pattern between the currentperiod national output and two-year lagged exports. We attributed this result to the rather artificial character of the export promotion program of the 1980 s, which was based on heavy subsidization and wage suppression. Exports had, in fact, a strong and robust counter-cyclical correlation with manufacturing real wages under all time horizons considered. Exchange rate depreciation was found to be counter-cyclical with the real GDP for the import substitutionist period (1969-1979), yet slightly pro-cyclical for the post-1980 period.

We also found evidence to support that the measurement of the price cycle through variations in the price level versus inflation rates does matter. Variations in the CPI revealed significant counter-cyclicality against GDP, yet the inflation rate of consumer and producer prices revealed no conclusive evidence on the nature of its cyclicality with real output. Variations in the CPI, however, indicated weak correlations with the cyclical deviations of the PSBR or real wage costs in manufacturing. This observation suggests that the behaviour of consumer prices can be explained by its inertial component, rather than by the cyclical impulses of fiscal deficits, wage costs or fluctuations in the monetary aggregates. 


\section{REFERENCES}

Abraham, K. and J. Haltiwanger, "Real Wages and the Business Cycle," Journal of Economic Literature, 33, 1995, p. 1215-1264.

Adelman, I., "Redrafting the Architecture of the Global Financial System: Editor's Introduction," World Development, 28, 6, 2000, p. 1053-1060.

Agenor, P. R, J. McDermott and E. Prasad, "Macroeconomic Fluctuations in Developing Countries: Some Stylized Facts," IMF Working Paper WP/99/35, 1999.

Agenor, P. R. and P. J. Montiel, Development Macroeconomics, Princeton University Press, 1996.

Alper, E., "Nominal Stylized Facts of Turkish Business Cycles," METU, Studies in Development, 25, 2, 1998, p. 233-244.

Backus, D. K. and P. J. Kehoe, "International Evidence on the Historical Properties of Business Cycles," American Economic Review, 82, 4, 1992, p. 864-882.

Balkan, E. and E. Yeldan, "Financial Liberalization in Developing Countries: The Turkish Experience," in Medhora, R. and J. Fanelli, eds., Financial Liberalization in Developing Countries, London, Macmillan Press, 1998.

Ball, L., G. Mankiw and D. Romer, "The New Keynesian Economics and the OutputInflation Trade-off," Brookings Papers on Economic Activity, 1998, p. 1-65.

Basu, S. and A. M. Taylor, "Business Cycles in International Historical Perspective," Journal of Economic Perspectives, 13, 2, 1999, p. 45-68.

Barro, R., "Economic Growth in A Cross Section of Countries," Quarterly Journal of Economics, 104, 1991, p. 407-443.

Barro, R. and X. Sala-i-Martin, Economic Growth, McGraw Hill, 1995.

Beveridge, S. and C. R. Nelson, "A New Approach to Decomposition of Economic Time Series into Permanent and Transitory Components with Particular Attention to Measurement of the Business Cycle," Journal of Monetary Economics, 7, 2, 1981, p. 151-174.

Blackburn, K. and M. O. Ravn, "Business Cycles in the United Kingdom: Facts and Fictions," Economica, 59, 1992, p. 383-401.

Blanchard, O. J. and S. Fischer, Lectures in Macroeconomics, Cambridge, The MIT Press, 1987.

Boratav, K., “Türkiye'de Popülizm: 1963-1976," Yapıt, November, 1983, p. 1-26.

, Türkiye'de Sosyal Sinıflar ve Bölüsüm, Istanbul, Gerçek, 1991.

, Krizin Dinamikleri ve Türkiye'nin Alternatif Sorunu, 1984 .

Boratav, K. and O. Türel, "Turkey," in L. Taylor ed., The Rocky Road to Reform, Cambridge, MA and London, MIT Press, 1993. 
Boratav, K., E. Yeldan and A. Köse, "Globalization, Distribution And Social Policy: Turkey: 1980-1998," Paper presented at the CEPA Conference on Globalization and Social Policy, New York, January 1999.

Boratav, K., O. Türel and E. Yeldan, "Dilemmas of Structural Adjustment and Environmental Policies under Instability: Post-1980 Turkey," World Development, 24, 2, 1996, p. 373-393.

Brandner, P. and K. Neusser, "Business Cycles in Open Economies: Stylized Facts for Austria and Germany," Weltwirtschaftliches Archives, 128, 1992, p. 67-87.

Burns, A. F. and W. C. Mitchell, Measuring Business Cycles, New York, National Bureau of Economic Research, 1946.

Celasun, M., "Trade and Industrialization in Turkey: Initial Conditions, Policy and Performance in the 1980s," in G. K. Helleiner ed., Trade Policy and Industrialization in Turbulent Times, London, Routledge, 1994.

Celasun, M. and D. Rodrik, "Debt, Adjustment and Growth: Turkey," in J. Sachs and S. M. Collins, eds., Developing Country Debt and Economic Performance, Country Studies, Chicago and London, The University of Chicago Press, 1989.

Chadha, B. and E. Prasad, "Are Prices Countercyclical? Evidence from the G-7," Journal of Monetary Economics, 34, 11994, p. 241-257.

Cizre-Sakallıglu, Ü. and E. Yeldan, "Politics, Society and Financial Liberalization: Turkey in the 1990s," Development and Change, 31, 2, 2000, p. 481-508.

Cizre-Sakallıoglu, Ü. and E. Yeldan, "Dynamics of Macroeconomic Disequilibrium and Inflation in Turkey: The State, Politics, and the Markets Under A Globalized Developing Economy," Paper prepared for the World Bank Study on "Issues Surrounding Disinflation in Turkey," Ankara, 1999.

Cochrane, J. H., "Permanent and Transitory Components of GNP and Stock Prices," Quarterly Journal of Economics, 109, 1, 1994, p. 241-265.

Cogley, T., "Evaluating Non-Structural Measures of the Business Cycle," Federal Reserve Bank of San Francisco Economic Review, 3, 1997, p. 2-21.

Cogley, T. and J. M. Nason, "Effects of the Hodrick-Prescott Filter on Trend and Difference Stationary Time Series: Implications for Business Cycle Research," Journal of Economic Dynamics and Controh 19,1-2, 1995, p. 253-278.

Devereux, M., "Real Exchange Rates and Macroeconomics: Evidence and Theory," Canadian Journal of Economics, 30, 1997, p. 773-808.

Dornbusch, R. and S. Fisher, "Stopping Hyperinflations Past and Present," Weltwirtschaftliches Archives, 122, 1, 1986, p. 1-47.

Ekinci, N., "Türkiye Ekonomisinde Büyüme ve Kriz Dinamikleri," Toplum ve Bilim 77, Summer, 1998, p. 7-27.

Englund, P., P. Torsten, and L.O.E. Svensson, "Swedish Business Cycles: 1861-1988," Journal of Monetary Economics, 30, 1992, p. 343-371. 
Harvey, A. C. and A. Jaeger, "Detrending, Stylized Facts and the Business Cycle," Journal of Applied Econometrics, 8, 3, 1993, p. 231-247.

Hodrick, R. J. and E. C. Prescott, "Postwar U.S. Business Cycles: An Empirical Investigation," Journal of Money, Credit, and Banking, 29, 1, 1997, p. 1-16.

Hoffmaster, A. and J. Roldos, "Are Business Cycles Different in Asia and Latin America?" International Monetary Fund Working Paper, 1997, 97/9.

King, R. G. and S. Rebelo, "Low Frequency Filtering and Real Business Cycles," Journal of Economic Dynamics and Control 17, 1-2, 1993, p. 207-31.

King, R. G., C. Plosser and S. Rebelo, "Production, Growth and Business Cycles I. The Basic Neoclassical Model," Journal of Monetary Economics, 21, 1988a, p. 195-232.

, "Production, Growth and Business Cycles II. The New Directions," Journal of Monetary Economics, 21, 1988, p. 309-341.

Köse, A. and E. Yeldan, "Turkish Economy in 1990s: An Assessment of Fiscal Policies, Labour Markets and Foreign Trade," New Perspectives on Turkey, 18, Spring, 1998.

Kydland, F. E. and E. Prescott, "Business Cycles: Real Facts and a Monetary Myth," Federal Reserve Bank of Minneapolis Quarterly Review, Spring, 1990, p. 3-18.

Levine, R. and D. Renelt, "A Sensitivity Analysis of Cross-Country Regressions," American Economic Review, 82, 1992, p. 942-963.

Lucas, R., "Understanding Business Cycles" Carnegie-Rochester Conference Series on Public Policy, 5, 1977, p. 7-29.

"Methods and Problems in Business Cycle Theory," Journal of Money, Credit, and Banking, 12, 1980, p. 696-715.

Metin, K., "An Integrated Analysis of Turkish Inflation," Oxford Bulletin of Economics and Statistics, 57, 1995, p. 513-531.

, "The Relationship Between Inflation and the Budget Deficit in Turkey," Journal of Business Economic Statistics, 16, 1998, p. 412-422.

Milanovic, B., "Export Incentives and Turkish Manufactured Exports: 1980-1984," World Bank Staff Working Paper, 602, 1986.

Minford, P., J. Riley and E. Nowell, "Trade, Technology and Labour Markets in the World Economy, 1970-1990: A Computable General Equilibrium Analysis," Journal of Development Studies, 34, 1997, 2, p. 1-34.

Obstfeld, M. and A. Taylor, "The Great Depression as a Watershed: International Capital Mobility in the Long-Run," in Bordo, M., C. Goldin and E. White, eds., The Defining Moment: The Great Depression and the American Economy in the Twentieth Century, Chicago, University of Chicago Press, 1998.

Onaran, Ö., "The Effects of Structural Adjustment Policies on the Labour Market and Income Distribution in Turkey," unpublished doctoral dissertation, Istanbul Technical University, 1999. 
Özatay, F., "The 1994 Currency Crisis in Turkey," Policy Reform, 1, 1, 1999, p. 1-26.

, "A Quarterly Macroeconomic Model for a Highly Inflationary and Indebted Country: Turkey," Economic Modelling, 17, 2000, p. 1-11.

Önis, Z. and A. Baysan, "Neo-Liberal Globalisation, the Nation-State and Financial Crises in the Semi-Periphery: A Comparative Analysis," Third World Quarterly, 21, 1, 1999, p. 119-139.

Pedersen, T. M., "How Long are Business Cycles? Reconsidering Fluctuations and Growth," University of Copenhagen, Institute of Economics, Discussion papers, 24, 1998.

Rodrik, D., "Development Strategies for the Next Century," Harvard University, John F. Kennedy School of Government, 2000.

Romer, C. D., "Changes in Business Cycles: Evidence and Explanations," Journal of Economic Perspectives, 13, 2, 1999, p. 23-44.

, “Remeasuring Business Cycles," Journal of Economic History, 54, 1994, p. 573-609.

"The Prewar Business Cycle Reconsidered: New Estimates of Gross National Product, 1869-1908," Journal of Political Economy, 97, 1989, p. 1-37.

, "Spurious Volatility in Historical Unemployment Data," Journal of Political Economy, 94, 1986, p. 1-37.

Rotemberg, J. and M. Woodford, "Markups and the Business Cycle," in Blanchard, $O$. and S. Fischer, ed., NBER Macroeconomics Annual: 1991, Cambridge, MA and London, MIT Press, 1991.

Sargent, T. J., “ The Ends of Four Big Hyperinflations," in R.E. Hall, ed., Inflation, University of Chicago Press, 1982.

Selçuk, F., "Consumption Smoothing and Current Account: Turkish Experience, 1987-1995," METU Studies in Development, 24, 4, 1997, p. 519-530.

Selçuk, F., and A. Rantanen, Türkiye'de Kamu Harcamaları ve Kamu Borçlanmast Istanbul, TUUSIAD Yay., 1996.

Singh, A., "Trade, Technology, Institutions, and Social Norms: A Perspective on the Determinants of Income Inequality," Paper presented at the UNU/WIDER International Workshop on "Rising Income Inequality and Poverty Reduction: Are They Compatible” Helsinki, July 1999.

Stiglitz, J., “Capital Market Liberalization, Economic Growth, and Instability," World Development, 28, 6, 2000, p. 1075-1100.

Sahinkaya, S., "Imalat Sanayiinde Sektörel Isgücü Verimliligi, Reel Úcretler ve Gayrisafi Karlar veya Mark-up Oranları (1963-1988 Türkiye Örnegi)," Toplum ve Ekonomi, 4, 1993.

Senses, F., "The Stabilization and Structural Adjustment Program and the Process of Turkish Industrialization: Main Policies and Their Impact," in Senses, F. ed., Recent Industrialization Experience of Turkey in A Global Context, Westport, CT, Greenwood Press, 1994. 
Taylor, L., Structuralist Macroeconomics: Applicable Models for the Third World New York, Basic Publications, 1981.

Tobin, J., "Financial Globalization," World Development, 28, 6, 2000, p. 1101-1104.

Togan, S., "How to Assess the Significance of the Export Incentives: An Application To Turkey," Weltwirtschaftliches Archives, 129, 4, 1993, p. 777-800.

Türel, O., "Restructuring the Public Sector in Post-1980 Turkey: An Assessment," Middle East Technical University, ERC Working Papers, 99/6, 1999.

Uçer, M., “Turkey's Inflation Myths: Observations on the 1998 Program,” Paper prepared for the World Bank Study on "Issues Surrounding Disinflation in Turkey," Ankara, 1999.

United Nations Conference on Trade and Development (UNCTAD), 1999 Trade and Development Report, Geneva, UNCTAD, 1999.

Uygur, E., "Erratic Growth and Private Investment Behaviour in Turkey," Ankara University, Faculty of Political Science, 1999, mimeo.

- Financial Liberalization and Economic Performance of Turkey, Ankara, The Central Bank of Turkey, 1993.

Van Els, P., "Real Business Cycle Models and Money: A Survey of Theories and Stylized Facts," Weltwirtschaftliches Archives, 131, 1995, p. 223-264.

Voyvoda, E. and E. Yeldan, "Labour Productivity and the Evolution of Industrial Wages in Turkey: A Quantitative Assessment," Bilkent University Department of Economics, Working Paper, 99-9, 1999.

Wood, A., North-South Trade, Employment, and Inequality: Changing Fortunes in a Skill Driven World, Oxford, Clarendon Press, 1994.

Yeldan, E., "The Impact of Financial Liberalization and the Rise of the Financial Rent on Income Inequality: The Case of Turkey," Paper presented at the UNU/WIDER International Workshop on "Rising Income Inequality and Poverty Reduction: Are They Compatible" Helsinki, 1999.

"Surplus Creation and Extraction under Structural Adjustment: Turkey, 19801992," Review of Radical Political Economics, 27, 2, 1995, 38-72.

Yeldan, E. and A. Köse, "An Assessment of The Turkish Labour Market Against its Macroeconomics Policies", in Bulutay, T., ed The Burdens Related with Turkish Labour Markets and Policies, Ankara, State Institute of Statistics, 1999.

Yentürk, N., "Short Term Capital Inflows and Their Impact on Macroeconomic Structure: Turkey in the 1990s," The Developing Economies, 37, 1, 1999, p. 89-113.

, Türk Imalat Sanayiinde Ucretler, Istihdam ve Birikim, Istanbul, Friedrich Ebert Stiftung, 1997. 
Yentürk, N. and Ö. Onaran, "Do Wages Stimulate Investments? An Analysis of the Relationship Between Wages and Investments in the Turkish Manufacturing Industry," Istanbul Technical University, Discussion papers in Management Engineering, 99, 11, 1999.

Zarnowitz, V., "Theory and History Behind Business Cycles: Are the 1990s the Onset of a Golden Age?" Journal of Economic Perspectives, 13, 2, 1999, p. 69-90.

\section{Data Sources}

Data for our analysis mostly come from the State Planning Organization, Main Economic Indicators, (http://www.dpt.gov.tr) and the State Institute of Statistics (SIS), Manufacturing Industry Annual Surveys (http://www.die.gov.tr), from which data on wages are derived. To arrive at wage rates, we have used data on total wages paid divided by average number of workers engaged. Large enterprises are defined as those workers employing more than 10 workers. We have updated our data on small enterprises wage rates from Bulutay (1995) Employment, Unemployment and Wages in Turkey, ILO/SIS, Ankara. Average labour productivity in fig. $3 \mathrm{a}$ is derived by dividing value added by average number of workers engaged. Data on the PSBR dates back to only 1975 from the Undersecretariat of Treasury sources, thus we had to contain our analysis on the PSBR for 1975 to 1999 . We have used the consumer price index in deflating nominal magnitudes. 